\title{
РЕПРОДУКТИВНЫЕ УСТАНОВКИ РОССИЯН И ОТНОШЕНИЕ К ГОСУДАРСТВЕННЫМ МЕРАМ ПОДДЕРЖКИ РОЖДАЕМОСТИ
}

\author{
ИРИНА ОСИПОВА
}

\begin{abstract}
Статья написана на основе опроса, выполненного Фондом «Общественное мнение» по заказу Агентства стратегических инициатив, а также других опросов ФОМ. Исследование посвящено репродуктивным установкам женщиин в возрасте 18-45 лет и мужчин 18-55 лет, а также оценке ими существующих и предполагаемых мер пронаталистской политики и их эффективности.

Результаты опроса показывают, что наиболее распространенная желаемая модель семьи по количеству детей за 10 лет не изменилась и остается двухдетной. Однако на сегодняшний день намерения многих россиян «отстают» от их желаний. Так, лишь четверть опрошенных планируют завести еще одного ребенка. Остальных чаще всего останавливает отсутствие стабильных источников дохода, достаточных для рождения и воспитания еще одного ребенка. Поэтому (хотя и не только) наиболее популярными мерами демографической политики сегодня являются материальные: материнский капитал за рождение второго ребенка (опрос был проведен еще до введения такового и за первого ребенка), погашение обязательств по ипотечным кредитам для многодетных семей, ежемесячное пособие по уходу за ребенком до полутора лет.

Демографы, однако, сомневаются в эффективности подобных мер, с точки зрения повышения рождаемости. Данные опросов в некотором смысле это подтверждают. Несмотря на то, что опрошеннье верят, что демографическая политика влияет на рождаемость, лишь немногие сами учитывали ее при принятии решения о том, заводить ребенка или нет.
\end{abstract}

Ключевые слова: рождаемость, репродуктивные намерения, желаемое количество детей, семейная политика, эффективность.

\section{ИНФОРМАЦИОННАЯ БАЗА}

Главным источником информации для этой работы является массовый поквартирный опрос Фонда «Общественное мнение» по заказу Агентства стратегических инициатив (АСИ), посвященный установкам россиян на рождение детей и их отношению к реальным и потенциальным мерам государственной поддержки рождаемости. Во избежание коммуникационных сбоев и для большей валидности данных мы ограничились опросом «целевой аудитории», под которой понимаем женщин в возрасте 18-45 лет и мужчин в возрасте 18-55 лет. Всего были опрошены 1030 респондентов: 583 (57\%) мужчин и 447 (43\%) женщин ${ }^{1}$. Другие социально-демографические параметры представлены в таблице 2. Опрос был проведен с 14 по 19 ноября 2019 г.

ИРИнА ОсиповА (osipova49@yandex.ru), Фонд "ОБщественное мнЕние", Россия.

СТАТЬЯ ПОСТУПИЛА В РЕДАКЦИЮ В МАРТЕ 2020 Г.

\footnotetext{
${ }^{1}$ Выборка опроса: репрезентативная общероссийская многоступенчатая стратифицированная случайная выборка. География опроса: 104 населенных пункта в 53 субъектах РФ. Статистическая погрешность не превышает 4,1\%
} 
Кроме того, мы использовали результаты еженедельных всероссийских опросов ФОМ («ФОМнибус», 1500 респондентов 18 лет и старше, 53 субъекта РФ) по релевантным темам. Данные этих опросов также были соотнесены с целевой аудиторией. Под каждым графиком и таблицей, в которых используются результаты опросов «ФОМнибус», указан источник данных с основными параметрами и датой опроса. Во всех иных случаях используются данные опроса по заказу АСИ.

\section{ВВЕДЕНИЕ}

Уже несколько десятилетий рождаемость (коэффициент суммарной рождаемости) в России, несмотря на ее кратковременный подъем в некоторые периоды, не превышает уровня простого воспроизводства населения. Последний такой подъем, как известно, пришелся на годы после активизации демографической политики в 2007 г., поэтому чиновники считают, что люди стали заводить больше детей благодаря их усилиям. В то же время многие демографы объясняют рост коэффициента суммарной рождаемости поиному. Они обращают внимание на то, что этот рост начался до введения новых мер демографической политики, и связывают его с реализацией рождений, отложенных в 1990е годы (Фрейка, Захаров 2014).

Как бы то ни было, сейчас период рост остался позади, начиная с 2015 г., коэффициент суммарной рождаемости в России снижается, свидетельствуя о том, что существующие меры демографической политики не оказались достаточно эффективными (особенно в условиях снижения темпов экономического роста) (Исупова 2018). Кроме того, первоначально ускорившееся в период активной пронаталистской политики формирование семей естественным образом привело к компенсаторному спаду, когда эффект введенных мер исчерпал себя. Некоторые демографы предсказывали этот спад (Фрейка, Захаров 2014).

Сами россияне едва ли осведомлены о том, как в нашей стране обстоят дела с рождаемостью: большая часть респондентов (39\%) уверены, что в последние два-три года уровень рождаемости растет. Они, так же, как и чиновники, судя по ответам на открытый вопрос, думают, что в этом есть заслуга демографической политики страны, в частности в качестве причин отмечают введение материнского капитала за второго ребенка (9\%), другую социальную помощь государства $(7 \%)$, в том числе выплату пособий. О том, что рождаемость снижается, говорят лишь четверть $(23 \%)$ россиян, при этом главной причиной они называют экономические проблемы в целом («ввиду того, что недостаточный уровень достатка в семьях»; «люди выживают, маленькие зарплатьл»; «возможно, связано с финансами. Людям не хватает, чтобы себя прокормить, а еще и дети»; «не на что содержать ребенка»; «уровень дохода резко снижсается, наличие одного ребенка превращает семью в нищих»; «зачем нищету плодить?» - 13\%), и лишь затем недостаточную поддержку государства («низкий уровень социиальной политики $u$ поддержки молодых семей»; «сочиальные условия не созданы для рождения детей»; «неправильная политика государства в социальной области»; «нет поддержки государства»; «правительство плохо заботится о населении»; «правительство плохое»; «государство неизвестно, где»-3\%); 21\% не видят никаких изменений, 16\% затруднились 
ответить. Впрочем, еще год назад о росте рождаемости говорили более половины опрошенных (57\%; таблица 1$)$.

Таблица 1. Распределение ответов на вопрос: «На Ваш взгляд, в последние два-три года уровень рождаемости в России растёт, снижается или не меняется?», \% от опрошенных

\begin{tabular}{l|c|c|c|c|c}
\hline & 21 мая & 18 марта & 27 марта & 15 апреля & Ноябрь \\
& 2006 & 2007 & 2011 & 2018 & 2019 \\
\hline Растёт & 24 & 37 & 53 & 57 & 39 \\
Снижается & 50 & 22 & 12 & 12 & 23 \\
Не меняется & 15 & 24 & 21 & 18 & 21 \\
Затрудняюсь ответить & 11 & 17 & 14 & 12 & 16 \\
\hline
\end{tabular}

Источник: Для 2006-2018 гг. приводятся данные опросов «ФОМнибус»: 104 населенных пункта, 53 субъекта РФ, 1500 респондентов. Рассчитано от целевой аудитории: мужчины 18-55 лет, женщины $18-45$ лет.

Тем не менее большинство опрошенных оптимистичны как в оценках условий для рождения детей за последние 10 лет, так и в видении перспектив в этом направлении (рисунки 1 и 2).

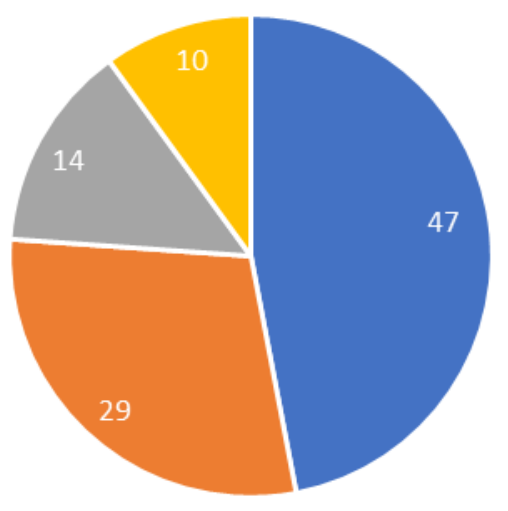

- лучше

- такие же

Рисунок 1. Распределение ответов на вопрос: «Как Вы считаете, сейчас в России условия для рождения детей лучше или хуже, чем 10 лет назад?», \% от опрошенных

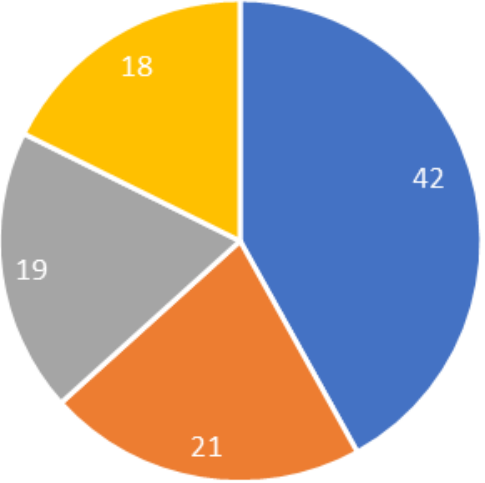

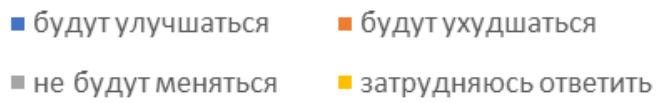

Рисунок 2. Распределение ответов на вопрос: «Как Вам кажется, условия для рождения детей в России в ближайшие

3-5 лет будут улучшаться или ухудшаться?», \% от опрошенных

Судя по ответам респондентов на открытый вопрос, недостаток мер государственной поддержки не является наиболее значимым фактором снижения рождаемости. В научной среде вокруг вопроса о возможности влияния государства на репродуктивное поведение населения до сих пор ведутся дискуссии (Исупова 2018: 28). Тем не менее власти все равно озабочены дополнительными мерами, которые могли бы стимулировать рождаемость.

Демографы уже пытались исследовать, каким образом пронаталистская политика последних лет, главной мерой которой стал материнский (семейный) капитал, повлияла на 
рождаемость россиян. Их главный вывод сводится к тому, что «ни сами намерения россиян, ни их реализация на массовом уровне не изменились существенным образом под влиянием действия мер пронаталистской политики. Некоторые положительные подвижки в репродуктивных установках имеются, но значимость их совершенно недостаточна, чтобы смотреть на будущее российской рождаемости с оптимизмом» (Захаров 2016: 8). Главным результатом, по мнению многих демографов, стало изменение календаря рождений: «тем, кто и так планировал еще одного ребенка, материнский капитал придал решимости, и они осуществили это намерение несколько раньше» (Слонимчик, Юрко 2016).

Кроме того, не в первый раз ученые пытаются выявить эффективность конкретных мер по стимулированию рождаемости через отношение к ним населения. Так, О. Исупова провела анализ Российской микропереписи 2015 г., в рамках которого исследовала отношение не только к существующим, но и к планируемым мерам, однако список позиций был несколько иным, чем в нашем исследовании. В результате было выявлено, что россияне предпочитают денежные выплаты немонетарным льготам, что связывается с «достаточно низкой средней официальной зарплатой в России, не в полной мере и не всем позволяющей удовлетворить нужды семьи при попытках заработать деньги самостоятельно» (Исупова 2018: 50).

В целом использование опросов в демографии распространено сейчас довольно широко. Их применяют не только для оценки эффективности реальных либо потенциальных мер и в целом получения «мнения» по определенным вопросам, но и для изучения репродуктивного поведения, что включает в себя изучение репродуктивных установок (в частности брачных установок и «поступков и оценок в вопросах деторождения»), оцениваемых на основе опросов, а также реального поведения, о котором позволяют судить статистические данные о рождаемости (Белова, Дарский 1972: 8).

Примерно до 1960-х годов прошлого века демографы при изучении рождаемости, в первую очередь, обращали внимания на социально-экономические показатели, в частности, условия жизни семей, которые считались определяющим фактором рождаемости, однако затем пришло понимание, что «социально-экономические условия воздействуют на демографические процессы через общественное сознание <..> Общественное сознание различными путями и прежде всего через социальные нормы, основанные на существующей системе ценностей, определяет поведение членов общества, в том числе и демографическое» (Белова, Дарский 1972: 34-36). Кроме того, репродуктивные установки и поведение человека формируются не столько под влиянием условий жизни в конкретный момент времени, сколько теми условиями, под влиянием которых формировалась личность. Поэтому демографы обратились к изучению относительно новых для себя показателей KAP (knowledge, attitudes, practice). Авторы цитированной выше работы «Статистика мнений в изучении рождаемости» В.А. Белова и Л.Е. Дарский (1972) не только составили список всех зарубежных опросов, посвященных репродуктивному поведению, но и провели одними из первых подобный опрос в СССР (правда, только среди женщин). Особенную актуальность этот опрос приобрел вследствие падения с 1960-х годов рождаемости и невозможности, соответственно, составления прогноза на основе прошлых тенденций. 
В качестве основных показателей, характеризующих репродуктивные намерения, обычно рассматривается «идеальное», «желаемое» и «ожидаемое» число детей (Белова, Дарский 1972: 24-26). «Идеальное» количество детей обычно отражает представления индивида о наилучшем числе детей в абстрактной семье без учета обстоятельств и намерений самой семьи. «Желаемое» число детей - это то, сколько детей хотел бы иметь человек без учета конкретных обстоятельств. «Планируемое» (или «ожидаемое») количество детей - это намерения человека относительно числа детей - то, сколько детей он планирует завести, учитывая конкретные обстоятельства на момент исследования (Бодрова 2002) $)^{2}$.

C середины XX века практически все демографы, изучающие рождаемость, в той или иной степени используют в своей работе данные опросов населения и задают как традиционные вопросы об идеальном, желаемом и планируемом числе детей, так и дополнительные: о факторах рождаемости, барьерах и др. Подобные исследования можно разделить на несколько групп.

В первой группе акцент делается на оценке потребности в детях и ее несовпадении с другими потребностями и условиями жизни (Борисов 1976; Варламова, Носкова, Седова 2006; Тындик 2012).

Вторая группа исследований - прикладные, на некоторые из них мы ссылались выше. Они направлены на оценку населением существующих и потенциальных мер по повышению рождаемости (Захаров 2016; Малева, Макаренцева, Третьякова 2017; Исупова 2018).

Исследования третьей группы посвящены индивидуальным репродуктивным «траекториям» женщин, в том числе с использованием лонгитюдных панелей (Freedman, Coombs 1965; Wilson, Bumpass 1973; Westoff, Ryder 1977). Одним из ключевых выводов подобных исследований является изменчивость установок на микроуровне в течение жизни конкретного человека. Но кроме того, используются и качественные методы исследования: глубинные интервью, фокус-группы и др. (Шадрина 2017; Attwood, Schimpfossl, Yusupova 2018). Они позволяют понять, чем руководствуется женщина (реже - семья), принимая решение завести ребенка, как она подходит к планированию беременности, как относится к воспитанию детей.

Настоящее исследование имеет смешанный формат и посвящено не только установкам в отношении детей, но и оценке существующих мер по поддержке рождаемости и потенциалу некоторых планирующихся мер (в том числе для многодетных семей).

\section{СОЦИАЛЬНО-ДЕМОГРАФИЧЕСКИЙ ПОРТРЕТ ЦЕЛЕВОЙ АУДИТОРИИ}

Ниже приведены основные социально-демографические характеристики опрошенной аудитории. Как можно отметить, респонденты распределены равномерно по уровню

\footnotetext{
2 Данные, анализируемые в этой статье, затрагивают лишь представления людей относительно желаемого и планируемого числа детей.
} 
образования, большинство из них живут в зарегистрированном браке, однако каждый третий еще в брак не вступил (таблица 2).

Таблица 2. Социально-демографический портрет целевой аудитории, \% от опрошенных

\begin{tabular}{llr}
\hline & $18-25$ лет & 10 \\
Мужчины & $26-35$ лет & 21 \\
& $36-45$ лет & 15 \\
& $46-55$ лет & 11 \\
\hline \multirow{3}{*}{ Женщины } & $18-25$ лет & 9 \\
& $26-35$ лет & 18 \\
& $36-45$ лет & 16 \\
\hline \multirow{2}{*}{ Образование } & среднее общее и ниже & 32 \\
& среднее специальное & 34 \\
& Высшее & 33 \\
\hline \multirow{2}{*}{ Семейное положение } & не женат (не замужем) и не был(-а) женат (замужем) & 30 \\
& разведен(-а) & 9 \\
& женат (замужем), брак зарегистрирован & 52 \\
& брак не зарегистрирован («гражданский» брак) & 8 \\
\hline
\end{tabular}

У трети опрошенных (32\%) детей нет, у 29\% есть один ребенок, у 26\% - двое, у 13\% - трое и более детей. Несмотря на малый объем выборки, наполненность этих групп, выделенных по количеству детей в семье, достаточна для того, чтобы анализировать каждую группу в отдельности (забегая вперед, отметим, что каждая из групп имеет свои особенности).

Так, среди не имеющих детей абсолютное большинство моложе 30 лет (70\%), 34\% в этой группе имеют высшее или неоконченное высшее образование, у 66\% материальное положение среднее и выше среднего, $30 \%$ проживают в городах-миллионниках и лишь 18\% - в селах. В основном это респонденты, не имеющие супруга (71\%).

Большинство имеющих детей респондентов состоят в зарегистрированном браке (68\%), еще 9\% живут в «гражданском» браке, 11\% разведены, 10\% не имеют супруга. Важно, что больше всего «семейных» людей (т. е. живущих в зарегистрированном браке) среди респондентов, имеющих двоих детей (75\% против 52\% по населению в целом), тогда как среди имеющих одного ребенка отношения оформлены лишь у $61 \%$ (11\% живут в «гражданском» браке, 14\% разведены, 11\% сказали, что не имеют супруга).

Любопытно, что выше всего доля живущих в незарегистрированных отношениях среди респондентов, имеющих трех и более детей: $14 \%$ против 9\% по опрошенным в целом (состоят в официальном браке $72 \%$ представителей этой группы). Возможно, это связано с тем, что эти люди уже состояли в официальном браке и, имея такой опыт (и, возможно, детей от этого брака), не стремятся официально оформить отношения с новым партнером (гипотеза требует дополнительной проверки). Однако, по всей видимости, в этой статистике играет свою роль и определенная «неблагополучность» подобных семей. Так, значительная часть многодетных родителей (79\%) из них не имеют высшего образования (против 67\% по всем опрошенных), 37\% живут в селах (против 26\% по всем опрошенных), трети из них денег хватает только на питание (34\% против 17\% по всем 
опрошенных). Таким образом, многодетными все еще зачастую становятся люди, имеющие ограниченные социальные ресурсы и капитал, хотя типы многодетных семей, конечно, этим не ограничиваются (Павлюткин 2017) .

\section{УСТАНОВКИ НАСЕЛЕНИЯ В ОТНОШЕНИИ ДЕТЕЙ}

На сегодняшний день наиболее распространенная желаемая модель семьи по числу детей двухдетная. О том, что хотели бы иметь двоих детей, если бы для этого были все условия, сказали $41 \%$ опрошенных. Немало и тех, кто хотел бы (в идеальном случае) иметь и троих детей - 30\%. Четверых и более детей хотели бы иметь 15\%. Согласно нашему опросу, лишь $6 \%$ хотели бы ограничиться только одним ребенком и $3 \%$ в принципе не хотели бы иметь детей. При этом за последнее десять лет установки россиян изменились не очень сильно (рисунок 3).

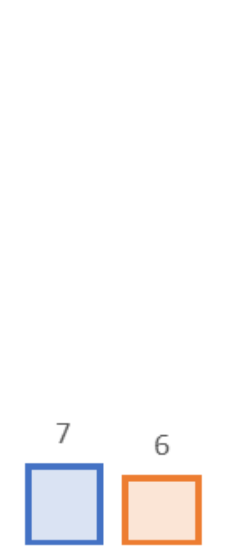

одного ребёнка

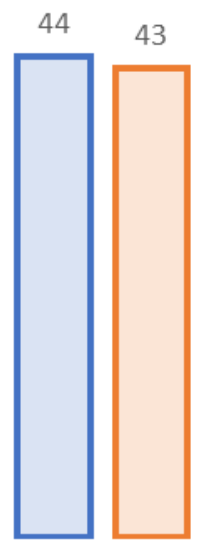

двоих детей

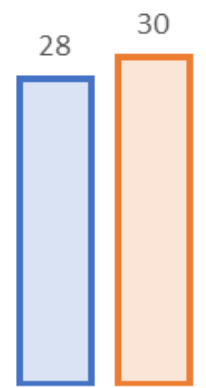

троих детей

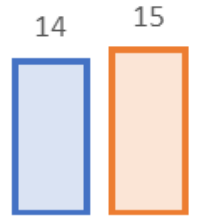

четверых и более детей

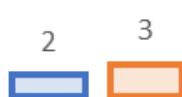

не хотел(-а) бы иметь детей

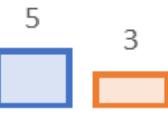

затрудняюсь ответить

口Май 2008 口Ноябрь 2019

Рисунок 3. Распределение ответов на вопрос: «Сколько детей Вы хотели бы иметь, если бы у Вас были для этого идеальные условия?», \% от опрошенных

Источник: Данные 2008 г. - из опроса «ФОМнибус» 24-25 мая 2008 г., 104 населенных пункта, 53 субъекта РФ. Данные приведены в расчете от целевой аудитории (мужчины 18-55 лет, женщины 18-45 лет). Данные 2019 г. - из исследования по заказу АСИ.

\footnotetext{
${ }^{3}$ Согласно исследованию «Рождаемость и социальные сети поддержки: исследование факторов создания многодетной семьи», «есть набор формальных признаков, позволяющий их [многодетные семьи - прим. автора] разделить: количество браков, количество детей и средний интервал рождений. Есть то, что мы назвали формальной многодетностью: когда третий или четвертый ребенок не был запланирован и его оставили. Есть многодетность как следствие нового качества родительских отношений. Или, когда у вас может быть 3-4 детей, но с интервалом рождения 4-5 лет. Есть многодетность как следствие религиозной социализации, для нее характерны узкий интервал рождения (не превышает 2-3 лет) и большое число детей. Также можно выделить группу семей, которые стали многодетными в силу социального «заражения», перенимания опыта со стороны образцовых семей». URL: https://www.proaist.ru/journal/vypusk-4/znacheniereligii-v-sovremennoy-rossiyskoy-rozhdaemosti-/
} 
Таким образом, если судить по данным опроса, алармистские сообщения о распространенности движения child-free или о преобладании установок на однодетную семью весьма преувеличены. Проведенное ранее исследование ФОМ, посвященное людям, не желающим иметь детей (child-free), показывает, что большинство россиян (55\%) попрежнему убеждены, что человек не может быть по-настоящему счастливым, если у него нет детей, хотя 28\% опрошенных уверены в обратном. И несмотря на то, что за 10 лет соотношение заметно изменилось в пользу последних, «ценность» детей остается весьма высокой (рисунок 4).

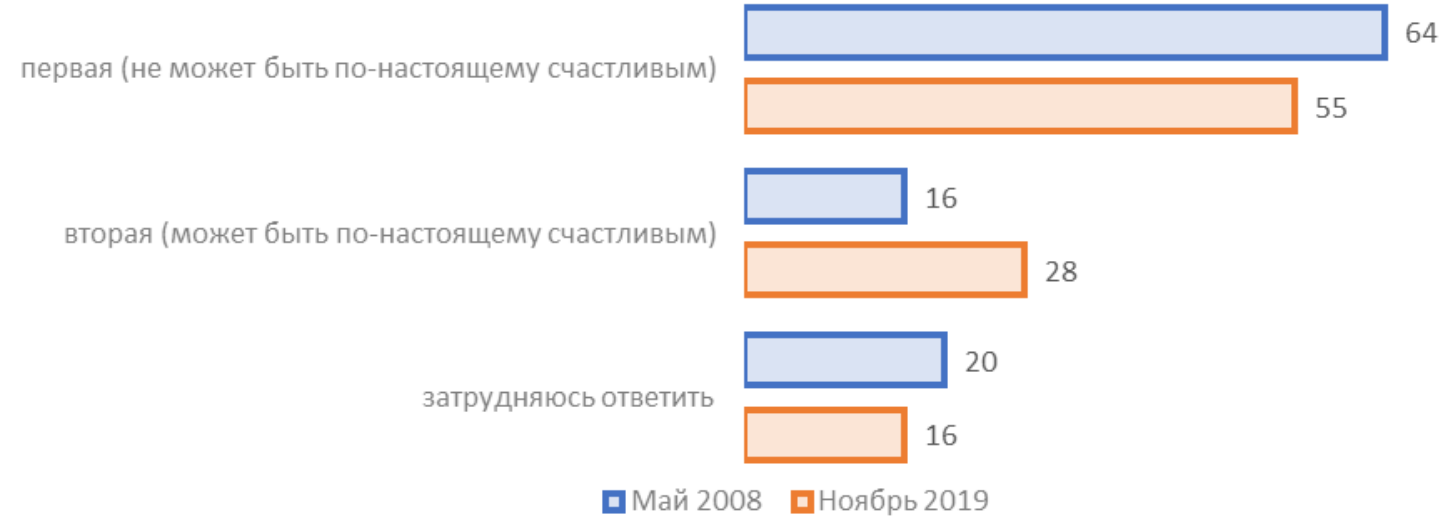

Рисунок 4. Распределение ответов на вопрос: «Одни считают, что если у взрослого, зрелого по возрасту человека нет детей, то он не может быть по-настоящему счастливым. Другие считают, что человек может быть по-настоящему счастливым, не имея детей. Какая точка зрения - первая или вторая - Вам ближе?», \% от опрошенных

Источник: Опрос «ФОМнибус», 104 населенных пункта, 53 субъекта РФ. Рассчитано от целевой аудитории: мужчины 18-55 лет, женщины 18-45 лет.

Интересно, что мужчины чаще женщин настроены (по крайней мере, на словах) на многодетную модель семьи: половина опрошенных в ходе исследования для АСИ мужчин (49\%) сказали, что хотели бы иметь, по меньшей мере, троих детей, тогда как среди опрошенных женщин так ответили 39\% (среди женщин каждая вторая (49\%) хотела бы иметь двоих детей). При этом, чем старше мужчина, тем больше детей он (на словах) хотел бы иметь, тогда как среди женщин подобной возрастной корреляции не наблюдается. Это может объясняться тем, что основная нагрузка по уходу за детьми и их воспитанию в России по-прежнему ложится на женщину, а не распределяется между партнерами, а потому они более «рационально» подходят даже к «мечтам».

Для оценки условного потенциала рождаемости (поскольку реальный потенциал оценивается на основе статистических данных реальных рождений) рассмотрим установки респондентов в зависимости от того, есть ли у них дети и сколько (таблица 3 ).

Мы видим, что для «однодетных» и «двухдетных» родителей идеальная семья - та, в которой два ребенка. Но среди тех, у кого уже есть двое детей, по меньшей мере каждый второй хотел бы иметь трех или более детей. Среди тех, у кого уже есть три ребенка, 
каждый второй (49\%) хотел бы иметь еще больше детей. Однако в этой же группе заметно выше доля тех, кто вообще не хотел бы детей (9\% против 3\% по населению в целом): вероятно, так отвечали родители незапланированных детей или же это эмоциональная реакция, вызванная жизненными трудностями в целом.

Таблица 3. Распределение ответов на вопрос: «А сколько детей хотели бы иметь Вы, если бы у Вас были для этого все необходимые условия?», \% от опрошенных

\begin{tabular}{l|c|c|c|c|c}
\hline & \multirow{2}{*}{$\begin{array}{c}\text { Все } \\
\text { опрошенные }\end{array}$} & \multicolumn{3}{|c}{ Число имеющихя детей } \\
\cline { 5 - 6 } & & 1 ребенок & 2 ребенка & $\begin{array}{c}3 \text { ребенка } \\
\text { и более }\end{array}$ & \multicolumn{2}{c}{$\begin{array}{c}\text { нет } \\
\text { детей }\end{array}$} \\
\hline Одного & 6 & 9 & 0 & 1 & 11 \\
Двоих & 43 & 52 & 42 & 2 & 51 \\
Троих & 30 & 28 & 38 & 36 & 24 \\
Четверых и более & 15 & 8 & 14 & 49 & 7 \\
Не хотел(-а) бы иметь детей & 3 & 2 & 3 & 9 & 2 \\
Затрудняюсь ответить & 3 & 1 & 3 & 3 & 5 \\
\hline
\end{tabular}

Необходимо также иметь в виду, что разрыв между установкой и практикой довольно велик и едва ли он вообще может быть преодолен: ведь фактически мы не знаем, что останавливает людей сегодня, какие условия им действительно необходимы для реализации желаемого. Однако некоторые изменения в ценностях и установках за последние десятилетия действительно произошли. Люди стали позже вступать в брак и создавать семью. Показателем успеха среди женщин сегодня являются не только семья и материнство, но самореализация и карьера. Кроме того, сейчас довольно широко распространена концепция «интенсивного материнствования», которая ставит нужды ребенка выше потребностей заботящихся взрослых, что трудно совместимо с развитием карьеры. Все это повышает «цену материнства», которую платит женщина при рождении ребенка, и приводит к откладыванию детей или рождению меньшего их числа (Шадрина 2017).

Статистические данные показывают, что в последние десятилетия средний возраст материнства неуклонно увеличивался (как и во всех развитых странах). В 2014 г. средний возраст материнства достиг максимума - 28,12 года, а средний возраст рождения первого ребенка составил 25,3 года. В то же время в самые последние годы темпы повышения среднего возраста материнства притормозились, однако возраст рождения первого ребенка продолжает расти. Это свидетельствует о том, что интервалы между рождением детей в семьях уменьшаются; иными словами, происходит «ускорение темпов формирования окончательного размера потомства в семьях» (Фрейка, Захаров 2014: 107). Авторы процитированного исследования полагают, что этому способствовала близость завершения государственных программ материнского капитала и пособий для поддержки многодетных семей, но эмпирических данных, способных подтвердить или опровергнуть эту гипотезу, пока нет (что указывает на необходимость более тщательного изучения этой проблемы).

Данные мониторинговых опросов ФОМ также подтверждают изменение установок в отношении «оптимального» возраста для рождения первого ребенка. За четыре года - с 2014 по 2018 - доля целевой аудитории (мужчин 18-55 лет и женщин 18-45 лет), считающая наиболее оптимальным для женщины возрастом рождения первого ребенка 21-24 года, 
снизилась с 51 до 38\% (рисунок 5). Все чаще люди считают оптимальным для женщины родить первого ребенка в возрасте 25-28 лет. Тем не менее большая часть целевой группы по-прежнему склоняется в пользу более младших возрастных групп. Впрочем, это неудивительно: большинству опрошенных в целевой группе женщин (38\%) как раз было от 21 до 24 лет, когда они родили первого ребенка, а многим - еще меньше (30\%).

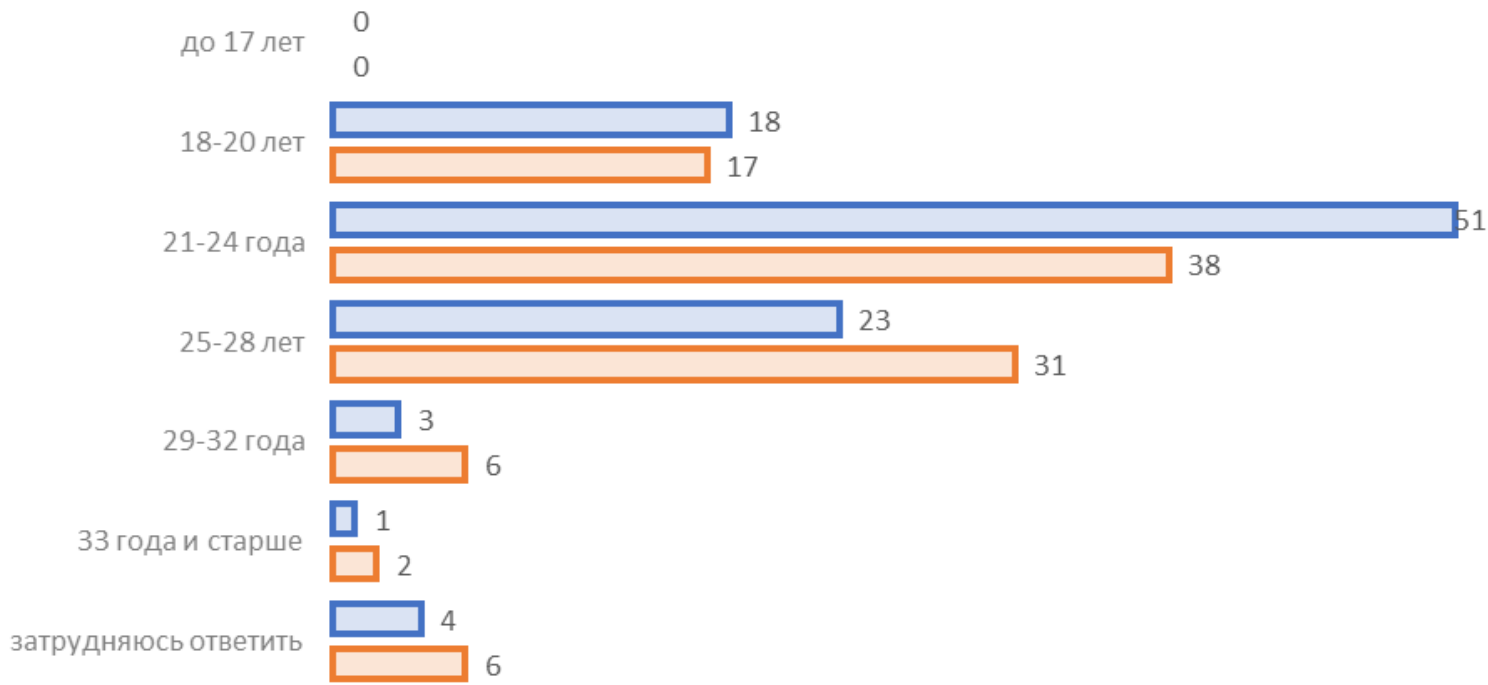

口Октябрь 2014 口Апрель 2018

\section{Рисунок 5. Распределение ответов на вопрос: «На Ваш взгляд, какой возраст для женщины сегодня является оптимальным, наилучшим для рождения первого ребёнка?», \% от опрошенных}

Источник: Опрос «ФОМнибус», 104 населенных пункта, 53 субъекта РФ. Рассчитано от иелевой аудитории: мужчины 18-55 лет, женщины 18-45 лет. 4-5 октября 2014 г., 14-15 апреля 2018 г.

В известной степени это несовпадение реального поведения (отраженного в статистике) и установок - фактически женщины рожают позже, чем считают «оптимальным», - может быть обусловлено все еще распространенной концепцией «позднородящих» матерей. В среднем, по данным омнибусного опроса ФОМ 2014 г., средний возраст «позднородящей» матери - 36 лет. А примерно четверть считают поздним ребенка, который родился, когда его матери было лишь 30-34 года. То есть фактический возраст рождения первого ребенка все ближе подбирается к возрасту, который некоторыми все еще считается «поздним».

Установки относительно возраста рождения детей обусловлены, помимо прочего, и типом населенного пункта, в котором проживает респондент. Большинство жителей городов-миллионников (в том числе Москвы) считают оптимальным возрастом для рождения первого ребенка 25 лет и более, тогда как среди сельчан большинство опрошенных считают, что женщина должна впервые родить до 24 лет (таблица 4).

Статистика также подтверждает, что изменения возрастного профиля рождаемости менее заметны у жителей сельской местности: и средний возраст матери, и средний возраст вступления в брак в селах растут меньшими темпами. Это дает демографам основания предположить, что в России сегодня существуют «две разные возрастные модели 
рождаемости: «модернизированная, постиндустриальная городская» (относительно более позднее родительство и более низкие нормы детности, эффективное планирование семьи) и «сельская, сохраняющая видовые черты прежнего, более традиционного прототипа» (относительно более ранее родительство, повышенные нормы детности, менее эффективное планирование семьи)» (Захаров 2016: 24).

Таблица 4. Распределение ответов на вопрос: «На Ваш взгляд, какой возраст для женщины сегодня является оптимальным, наилучшим для рождения первого ребёнка?», \% от опрошенных

\begin{tabular}{|c|c|c|c|c|c|c|c|}
\hline & \multirow{2}{*}{$\begin{array}{c}\text { Bсе } \\
\text { опрошенные }\end{array}$} & \multicolumn{6}{|c|}{ Тип населенного пункта } \\
\hline & & Москва & $\begin{array}{c}\text { города } 1 \\
\text { млн } \\
\text { и более }\end{array}$ & $\begin{array}{c}\text { города от } \\
250 \text { тыс. } \\
\text { до } 1 \text { млн }\end{array}$ & $\begin{array}{c}\text { города от } 50 \\
\text { до } 250 \text { тыс. }\end{array}$ & $\begin{array}{c}\text { города } \\
\text { менее } 50 \\
\text { тыс., ПГТ }\end{array}$ & сёла \\
\hline До 17 лет & 0 & 0 & 0 & 0 & 1 & 0 & 1 \\
\hline 18-20 лет & 17 & 11 & 12 & 12 & 13 & 26 & 21 \\
\hline 21-24 года & 38 & 34 & 35 & 38 & 37 & 35 & 45 \\
\hline $25-28$ лет & 31 & 37 & 39 & 37 & 34 & 23 & 25 \\
\hline 29-32 года & 6 & 11 & 9 & 4 & 6 & 6 & 3 \\
\hline 33-35 лет & 2 & 0 & 3 & 2 & 2 & 2 & 1 \\
\hline 36-40 лет & 0 & 0 & 0 & 0 & 1 & 0 & 0 \\
\hline 41 год и старше & 0 & 0 & 0 & 0 & 0 & 1 & 0 \\
\hline $\begin{array}{l}\text { Затрудняюсь } \\
\text { ответить }\end{array}$ & 6 & 7 & 3 & 8 & 6 & 8 & 4 \\
\hline
\end{tabular}

Источник: Опрос «ФОМнибус», апрель 2018 г., 104 населенных пункта, 53 субъекта РФ. Рассчитано от целевой аудитории: мужчины 18-55 лет, женщиины 18-45 лет.

Примечание: ПГТ - поселок городского типа.

Многие политики связывают сокращение числа рождений с изменениями в брачной структуре населения - «люди с меньшей охотой женятся». Они исходят из того, что партнеры, находящиеся в зарегистрированном браке, традиционно более склонны к рождению ребенка. Однако, по данным нашего исследования, по меньшей мере 35\% респондентов, проживающих в незарегистрированном браке, имеют ребенка. Среди неженатых и незамужних респондентов ребенок или дети есть у каждого пятого (20\%). Более того, согласно неопубликованной статистике Росстата, «за полтора прошедших десятилетия число браков существенно выросло (и в абсолютном, и в относительном измерении), брачная структура населения значительно улучшилась» (Захаров 2016: 13).

Тем не менее есть основания полагать, что смысл семьи, вступления в брак несколько изменился: люди женятся (выходят замуж) только тогда, когда решают завести ребенка, т. е. фактически именно для того, чтобы завести ребенка (детей). Об этом косвенно говорят распределения ответов на вопрос о том, когда респондент принял решение завести ребенка - до или после вступления в брак (вопрос, разумеется, задавали только тем, кто состоит или состоял в браке и у кого есть дети). Результаты анализа демонстрируют существование двух моделей поведения: традиционной, которая характерна для опрошенных старше 35 лет, и современной, которой руководствуется молодежь. Практически половина опрошенных младше 35 лет приняли решение завести ребенка до вступления в брак, тогда как среди респондентов старше 36 лет основная масса приняла это 
решение после заключения брака (или, по меньшей мере, сказали так; таблица 5). Необходимо учесть, что для некоторых респондентов этот вопрос мог показаться сензитивным, намеком на «брак по залету», поэтому мы можем говорить лишь о зависимостях, а не о реальных цифрах.

Таблица 5. Распределение ответов на вопрос: «Вы приняли решение завести ребенка со своим партнером до или после заключения брака?», \% от опрошенных

\begin{tabular}{l|c|r|r|r|r}
\hline & \begin{tabular}{c} 
Состоящие (или \\
состоявшие) в браке и \\
\cline { 5 - 6 }
\end{tabular} & $18-25$ & $26-35$ & $36-45$ & $46-55$ \\
\hline Доеющие детей & & 47 & 46 & 34 & 16 \\
По заключения брака & 37 & 51 & 52 & 59 & 71 \\
После заключения брака & 57 & 2 & 2 & 8 & 13 \\
\hline
\end{tabular}

На репродуктивные установки людей в значительной степени влияет то, сколько детей было в семье, в которой они выросли. Особенно это касается выросших в многодетных семьях: среди них 55\% хотели бы иметь троих и более детей. Среди выросших лишь с одном братом или сестрой большинство (48\%) и сами хотели бы завести двоих детей. Исключение составляют единственные в семье дети - среди них лишь $12 \%$ хотели бы ограничиться одним ребенком, а большинство также предпочитают «двухдетную» модель семьи (таблица 6).

Таблица 6. Распределение ответов на вопрос: «А сколько детей хотели бы иметь Вы, если бы у Вас были для этого все необходимые условия?», \% от опрошенных

\begin{tabular}{l|c|c|c|c}
\hline & Опрошенные & \multicolumn{2}{|c}{ Число детей в семье, в которой вырос респондент } \\
\cline { 3 - 5 } & в целом & один ребенок & два ребенка & трое и более детей \\
\hline Одного ребёнка & 6 & 12 & 6 & 4 \\
Двоих детей & 43 & 46 & 48 & 33 \\
Троих детей & 30 & 26 & 30 & 34 \\
Четверых и более детей & 15 & 11 & 11 & 22 \\
Не хотел(-а) бы иметь детей & 3 & 2 & 3 & 4 \\
Затрудняюсь ответить & 3 & 2 & 3 & 4 \\
\hline
\end{tabular}

При анализе установок и их «прогностической» ценности необходимо учитывать, что они изменчивы не только на макроуровне (на уровне поколения), но и на микроуровне - человек может изменить свое мнение под влиянием каких-либо факторов. «Факторами, влияющими на характер репродуктивных установок, выступают образование и история занятости на рынке труда, наряду с историей создания и распада союзов, а также влияние предпочтений партнера» (Тындик 2012). Кроме того, помимо «идеального» числа детей есть более «реалистичное» с предсказательной точки зрения (если об этом в принципе можно говорить) «ожидаемое» количество детей. В данном исследовании наиболее близким показателем к «ожидаемому количеству детей» является ответ на вопрос о том, планирует ли респондент завести детей, и если да, то сколько (таблица 7).

Как можно увидеть, «двухдетные» и многодетные семьи с наименьшей вероятностью готовы обзавестись еще одним ребенком (несмотря на распространенность среди них установки на многодетность), основная «нагрузка» ложится на тех, у кого один ребенок или же вообще нет детей. 
Таблица 7. Распределение ответов на вопрос: «Вы планируете или не планируете заводить детей (ещё детей)? Если да, то сколько (ещё) детей Вы планируете завести?», \% от опрошенных

\begin{tabular}{l|c|c|c|c|c}
\hline & Опрошенные & \multicolumn{4}{|c}{ Число имеющихся детей } \\
\cline { 3 - 6 } & в целом & $\begin{array}{c}\text { один } \\
\text { ребенок }\end{array}$ & $\begin{array}{c}\text { два } \\
\text { ребенка }\end{array}$ & $\begin{array}{c}\text { трое детей и } \\
\text { более }\end{array}$ & $\begin{array}{c}\text { нет } \\
\text { детей }\end{array}$ \\
\hline Не планирую & 50 & 44 & 75 & 72 & 27 \\
Одного & 22 & 36 & 19 & 13 & 16 \\
Двух & 16 & 12 & 1 & 4 & 35 \\
Трёх & 4 & 2 & 0 & 2 & 11 \\
Четырёх и более & 3 & 2 & 2 & 4 & 4 \\
Затрудняюсь ответить & 5 & 5 & 3 & 4 & 7 \\
\hline
\end{tabular}

Несмотря на относительно небольшую долю людей, принципиально отказывающихся от рождения детей (child-free), и ее незначительный вклад в снижение рождаемости, в долговременной перспективе рост этой доли может иметь заметные последствия. По исследованиям демографов, за последние 15 лет вероятность первых рождений остается стабильной, однако, если не будет происходить ее увеличения, то база для дальнейшего роста вторых и последующих детей будет сокращаться. «Если интенсивность рождения первенцев будет продолжать оставаться на том же уровне, что в 1999-2014 гг., то ожидаемая величина окончательно бездетных женщин (не имевших ни одного живорождения к возрасту 50 лет) составит в среднем 16\%» (Захаров 2016: 31). Таким образом, увеличится «нагрузка» на уже родивших матерей: для естественного воспроизводства населения они должны будут рожать в среднем 2,5 ребенка.

\section{ОЦЕНКА ГОСУДАРСТВЕННЫХ МЕР ПО ПОВЫШЕНИЮ РОЖДАЕМОСТИ}

Демографы и социологи выделяют два типа мер, поддерживающих рождаемость: 1) направленные на баланс занятости и родительства; 2) ориентированные на материальную поддержку родителей. Результаты международных исследований показали, что жители западных стран склонны больше поддерживать меры первого типа, в частности улучшение возможностей частичной занятости и гибкой занятости, тогда как страны Восточной Европы предпочитают финансовые меры (Population Policy Acceptance... 2006: 49). Россия в этом смысле относится ко второй группе стран.

В рамках опроса для АСИ мы предложили респондентам выбрать из списка наиболее значимые, по их мнению, меры поддержки рождаемости. Опрос был проведен до введения материнского капитала за первого ребенка, поэтому в список эта мера не вошла, однако мы задали несколько вопросов об отношении к этой мере уже за рамками этого проекта и расскажем о результатах далее.

До введения материнского капитала за первого ребенка самыми важными мерами государственной поддержки оказались базовый материнский (семейный) капитал после рождения второго ребенка (60\%), погашение обязательств по ипотечным кредитам для многодетных семей (48\%), а также ежемесячное пособие по уходу за ребенком до полутора лет $(46 \%)$. Реже всего опрошенные респонденты упоминали недавно отмененное ежемесячное пособие по уходу за ребенком от полутора до трех лет в размере 50 рублей - 
$8 \%$, из чего можно сделать вывод, что реальными адресатами этой помощи было еще меньше людей (таблица 8).

Таблица 8. Распределение ответов на вопрос: «В России существуют различные меры государственной поддержки рождаемости. Посмотрите на карточку.

Какие из перечисленных на ней мер поддержки, на Ваш взгляд, наиболее значимы?» (не более трех ответов), \% от опрошенных

\begin{tabular}{l|c}
\hline Базовый материнский капитал после рождения второго ребёнка (453 026 рублей) & 60 \\
\hline $\begin{array}{l}\text { Погашение обязательств по ипотечным жилищным кредитам (займам) } \\
\text { для многодетных семей (450 000 рублей) }\end{array}$ & 48 \\
\hline $\begin{array}{l}\text { Ежемесячное пособие по уходу за ребёнком до полутора лет (сохранение } 40 \% \text { от } \\
\text { среднего заработка, но не более } 26152 \text { рублей) }\end{array}$ & 46 \\
\hline $\begin{array}{l}\text { Предоставление семьям с двумя детьми ипотечного кредита по ставке до 6\% на весь } \\
\text { срок кредита (после } 2022 \text { г. - с тремя детьми) }\end{array}$ & 36 \\
\hline Единовременное пособие при рождении ребёнка (8000 рублей) & 29 \\
\hline $\begin{array}{l}\text { Ежемесячная выплата до полутора лет в размере регионального прожиточного } \\
\text { минимума для ребёнка (если доход семьи ниже, чем полтора прожиточных } \\
\text { минимума на человека) }\end{array}$ & 24 \\
\hline Единовременное пособие по беременности (655 рублей) & 13 \\
\hline Ежемесячное пособие по уходу за ребёнком от полутора до трёх лет (50 рублей) & 8 \\
\hline Другое & 3 \\
\hline Затрудняюсь ответить & 7 \\
\hline
\end{tabular}

Важно, что этот список актуален для всех вне зависимости от числа уже имеющихся детей, за одним неочевидным исключением: те, у кого детей еще нет, чаще отмечают важность возможности погасить обязательства по ипотечным кредитам для многодетных семей $(53 \%)$.

Таблица 9. Распределение ответов на вопрос: «О каких из перечисленных на карточке мер поддержки рождаемости Вы не слышали до нашего опроса?», \% от опрошенных

\begin{tabular}{l|c}
\hline $\begin{array}{l}\text { Предоставление семьям с двумя детьми ипотечного кредита по ставке до 6\% на весь } \\
\text { срок кредита (после 2022 г. - с тремя детьми) }\end{array}$ & 33 \\
\hline $\begin{array}{l}\text { Погашение обязательств по ипотечным жилищным кредитам (займам) } \\
\text { для многодетных семей (450 000 рублей) }\end{array}$ & 26 \\
\hline Единовременное пособие по беременности (655 рублей) & 22 \\
\hline Ежемесячное пособие по уходу за ребёнком от полутора до трёх лет (50 рублей) & 19 \\
\hline $\begin{array}{l}\text { Ежемесячное пособие по уходу за ребёнком до полутора лет (сохранение 40\% от } \\
\text { среднего заработка, но не более 26 152 рублей) }\end{array}$ & 18 \\
\hline Единовременное пособие при рождении ребёнка (8000 рублей) & 16 \\
\hline $\begin{array}{l}\text { Ежемесячная выплата до полутора лет в размере регионального прожиточного } \\
\text { минимума для ребёнка (если доход семьи ниже, чем полтора прожиточных } \\
\text { минимума на человека) }\end{array}$ & 8 \\
\hline Базовый материнский капитал после рождения второго ребёнка (453 026 рублей) & 6 \\
\hline Другое & 26 \\
\hline Затрудняюсь ответить & 2 \\
\hline
\end{tabular}

Однако «запросы» к государству все же несколько различаются в зависимости от других социально-демографических характеристик опрошенной категории. Так, мужчины, в среднем, реже женщин склонны считать какую-либо государственную помощь для родителей важной, значимой, тогда как для женщин особенно важны базовый материнский (семейный) капитал, ежемесячное пособие по уходу за ребенком до полутора лет, предоставление «двухдетным» семьям ипотечного кредита по ставке до 6\%. 
Интересным образом на оценку значимости пронаталистских мер влияет образование респондентов: чем оно выше, тем чаще респонденты выбирают меры, направленные на помощь в улучшении жилищной ситуации, - уже упомянутую возможность погашения ипотечного кредита (54\%), а также снижение ставки ипотечного кредита для семей с двумя детьми (43\%). Это говорит о том, что среди высокообразованных россиян запрос на прямую финансовую помощь ниже и «спросом» пользуются именно меры непрямой помощи.

Отметим, что многие респонденты именно в ходе опроса впервые узнали о существовании обозначенных мер поддержки, что говорит о довольно низкой информированности о мерах государственной политики (таблица 9).

\section{ОТНОШЕНИЕ К ВВЕДЕНИЮ МАТЕРИНСКОГО КАПИТАЛА ПОСЛЕ РОЖДЕНИЯ ПЕРВОГО РЕБЕНКА}

Большинство женщин 18-45 лет и мужчин 18-55 лет (86\%) относятся к введению материнского капитала после рождения первого ребенка положительно, отрицательно оценили эту идею лишь 7\% (7\% затруднились ответить). Однако по большей части эта мера воспринимается не как демографическая, потенциально повышающая рождаемость, а как исключительно экономическая - как материальная помощь («какая-то финансовая поддержка от государства»; «помощь ощутимая», «подмога какая-то»; «хоть какая-то помощьъ»; «любая помощь хороша» (26\%)), которая поддержит молодые семьи («молодая семья только организуется, надо помогать»; "молодёжь женится, надо помогать»; «молодежи нужна поддержка, мамы и папь сейчас уже не помогут»; «поддержка молодым родителям»; «выходят замуж и студенты» (10\%)). Лишь затем находятся ответы, связанные с эффективностью этой меры в отношении повышения рождаемости: «мотиватор для рождаемости»; «народ русский должен размножаться»; «поднять естественный прирост населения»; «рожать более будут»; «хочется, чтоб население множилось»; «чтобы повысить демографию, стимулировать граждан обзаводиться детьми» $(10 \%)$.

Отвечая на соответствующий закрытый вопрос, лишь 39\% опрошенных сказали, что введение материнского капитала за первого ребенка существенно повысит рождаемость в стране, однако, во многом из-за меркантильности населения. Так ответил каждый четвертый сторонник этого мнения: «будут рожать из-за денег, не думая о будущем»; «все захотят получить легкие деньги»; «многие люди будут рожать за эти деньги»; «погоня за деньгами»; «соблазн получить деньги» $(10 \%)^{4}$. Лишь затем люди говорили, что материнский капитал за первого ребенка станет не стимулом, но дополнительным фактором, подспорьем для молодых семей, их «стартовым капиталом»: «копейка идет, полегче семье-то будет»; «боятся рожать, так как не на что содержать»; «все дорого,

\footnotetext{
${ }^{4}$ По данным ответов на открытый вопрос: «Почему Вы считаете, что введение материнского капитала за первого ребёнка приведёт к значительному повышению рождаемости?», - отвечали $39 \%$ респондентов. 
и это поможет содержать ребенка»; «людям нужен на поднятие ребенка начальный капитал» $(9 \%)$.

Однако большинство респондентов считают, что эта мера либо никак не скажется на рождаемости (27\%), либо повысит ее не очень значительно (24\%). Выбравшие эти позиции верят, что люди рожают не из-за денег: «дети не из-за денег рождаются»; «кто хочет рожать, все равно рожает, независимо от денег»; «люди рожают для себя, а не ради денег»; "на деньги не смотрят, если нужен ребенок»; «не о деньгах думают люди, а о детях» (12\%). К тому же выплата разовая и не в очень большом размере («в городе не очень большая сумма»; «деньги кончатся быстро, а человека надо растить»; «потому что впереди целая жизнь»; «единоразовая выплата»; «сумма разовая» (7\%)), а растить детей дорого («все детское очень дорогое, одежда очень дорогая»; «дети обходятся дороже»; «кормить, обуть, одеть, образование дать»; «сложно детей воспитыввать, поднимать» $(4 \%))$.

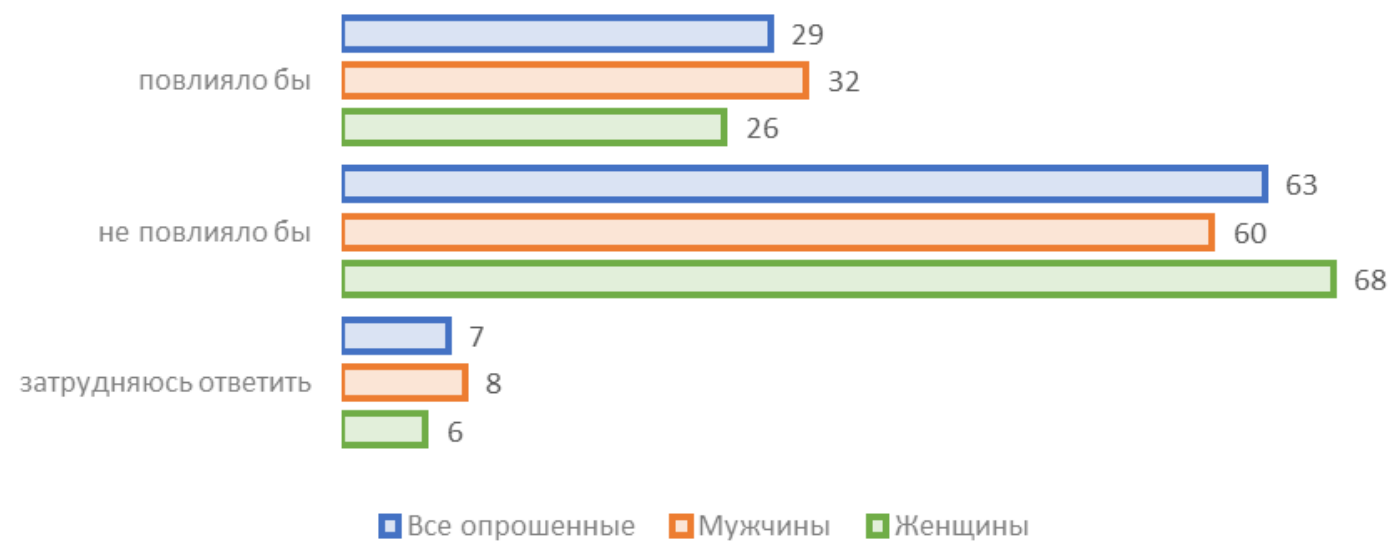

\section{Рисунок 6. Распределение ответов на вопрос: «Если бы Вы задумывались о рождении первого ребёнка, как Вам кажется, введение материнского капитала повлияло бы на Ваши планы и намерения или нет?», \% от опрошенных}

Источник: Опрос «ФОМнибус», февраль 2020 г., 104 населенных пункта, 53 субъекта РФ. Рассчитано от иелевой аудитории: мужчины 18-55 лет, женщины 18-45 лет.

Лишь 29\% опрошенных сказали, что введение материнского капитала за первого ребенка повлияло бы на их намерения (если бы они задумывались об этом). На большинство респондентов эта мера не оказала бы никакого влияния, однако любопытно, что мужчины в среднем чаще склонны учитывать эту меру, чем женщины. Это может объясняться разным подходом к решению завести ребенка. Женщина, поскольку на ней до сих пор больше ответственности в отношении воспитания детей, принимая решение завести ребенка, учитывает не только финансовую стабильность и материальные возможности, но и оценивает свою готовность выпасть на время с рынка труда, поменять привычный образ 
жизни, приоритеты. Тогда как образ жизни мужчины с появлением ребенка меняется менее разительно, а потому сдерживающих факторов у них зачастую меньше (рисунок 6) ${ }^{5}$.

Если говорить о личных установках бездетных россиян, то введение материнского капитала за первого ребенка никак (по крайней мере, пока) не повлияло на них. И до его введения, и после доля планирующих завести ребенка в ближайшие 2-3 года среди тех, у кого еще нет детей, составляет 38-39\% (рисунок 7).

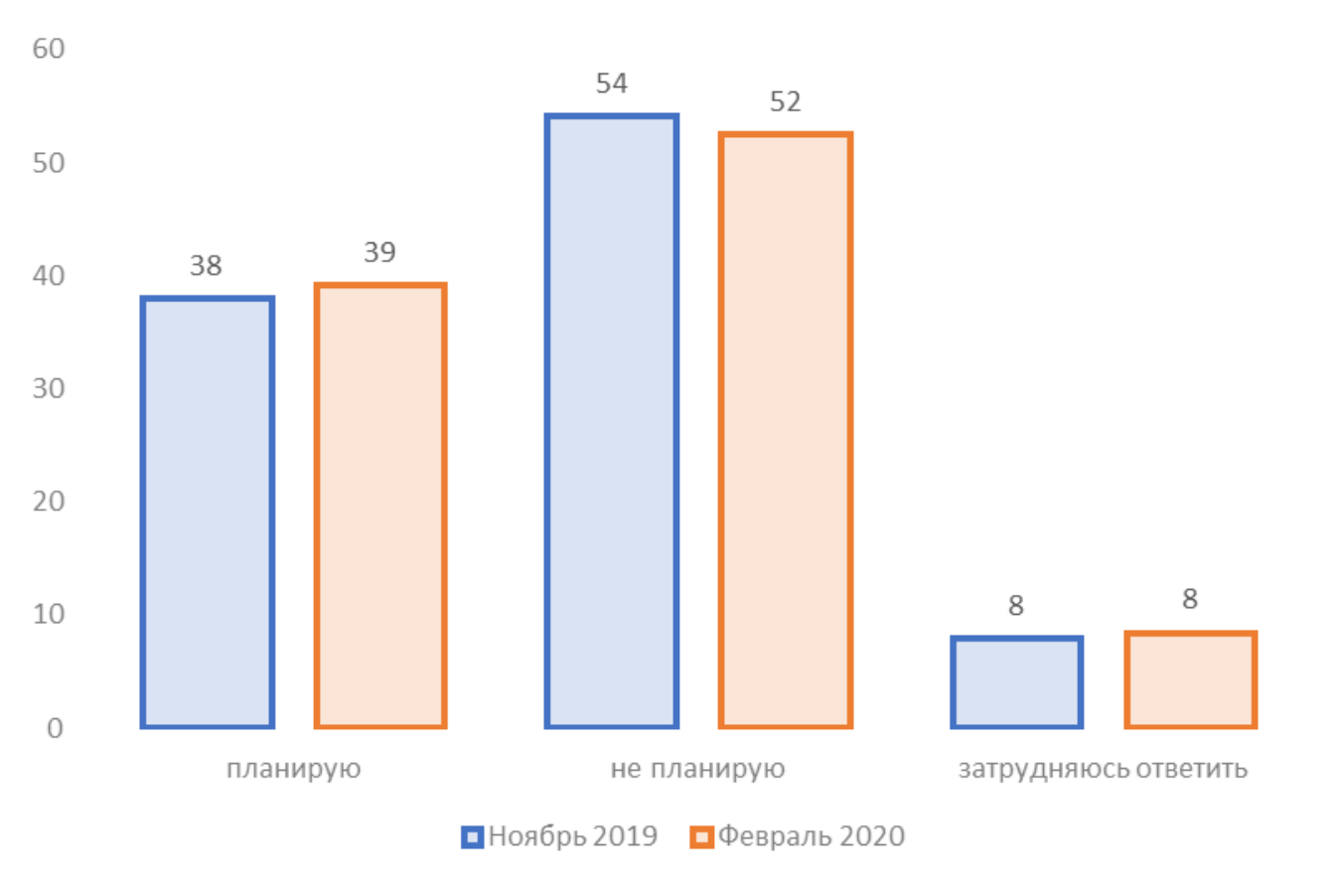

\section{Рисунок 7. Распределение ответов на вопрос: «Вы планируете или не планируете завести ребёнка (детей) в ближайшие 2-3 года?», \% от опрошенных}

Источник: Опрос «ФОМнибус», февраль 2020 г., 104 населенных пункта, 53 субъекта РФ. Рассчитано от иелевой аудитории: мужчины 18-55 лет, женщины 18-45 лет.

Это является неким подтверждением мнения демографа А. Вишневского, который оценивает эту меру не как демографическую, а как социальную помощь семьям и способ уменьшить бедность ${ }^{6}$, однако, судя по результатам опроса, это еще и не самый эффективный способ. Чем менее обеспечен респондент, тем чаще он считает, что сумма выплаты (около 460 тыс. рублей) - не очень существенная, что может являться дополнительной иллюстрацией глубины бедности в России (таблица 10).

\footnotetext{
${ }^{5}$ По данным других вопросов в рамках опроса для АСИ женщины чаще мужчин выбирали такие причины, по которым они откладывают или отказываются от рождения ребенка: «ребенок изменит привычный образ жизни» (7\% среди мужчин против 10\% среди женщин), «рождение ребенка помешает профессиональному росту матери» (3\% против 8\%), «некому помогать ухаживать за детьми» (6\% против 9\%).

${ }^{6}$ Путин пообещал выплачивать материнский капитал за первого ребенка, чтобы вывести страну из демографической ловушки (2020). URL: https://meduza.io/feature/2020/01/15/putin-poobeschal-vyplachivatmaterinskiy-kapital-za-pervogo-rebenka-chtoby-vyvesti-stranu-iz-demograficheskoy-lovushki
} 
Таблица 10. Распределение ответов на вопрос: «Предполагается, что размер материнского капитала за первого ребёнка составит около 460 тысяч рублей. Как Вам кажется, в вашем городе (посёлке, селе) для большинства семей, планируюших рождение первого ребёнка, это существенная или не очень существенная сумма?», \% от опрошенных

\begin{tabular}{|c|c|c|c|c|c|c|}
\hline & \multirow{2}{*}{$\begin{array}{c}\text { Опрошенные } \\
\text { в целом }\end{array}$} & \multicolumn{5}{|c|}{ Материальное положение семьи } \\
\hline & & $\begin{array}{c}\text { денег не } \\
\text { хватает на } \\
\text { питание }\end{array}$ & $\begin{array}{c}\text { на питание } \\
\text { хватает, на } \\
\text { одежду - } \\
\text { нет }\end{array}$ & $\begin{array}{c}\text { на одежду } \\
\text { хватает, на } \\
\text { крупную } \\
\text { бытовую } \\
\text { технику - } \\
\text { нет }\end{array}$ & $\begin{array}{c}\text { на } \\
\text { бытовую } \\
\text { технику } \\
\text { хватает, на } \\
\text { автомобиль } \\
\text { - нет }\end{array}$ & $\begin{array}{c}\text { на } \\
\text { автомобиль } \\
\text { хватает }\end{array}$ \\
\hline Существенная & 71 & 58 & 66 & 74 & 72 & 75 \\
\hline $\begin{array}{l}\text { Не очень } \\
\text { существенная }\end{array}$ & 24 & 37 & 28 & 20 & 24 & 19 \\
\hline $\begin{array}{l}\text { Затрудняюсь } \\
\text { ответить }\end{array}$ & 5 & 5 & 6 & 6 & 4 & 5 \\
\hline
\end{tabular}

Источник: Опрос «ФОМнибус», февраль 2020 г., 104 населенных пункта, 53 субъекта РФ.

Рассчитано от иелевой аудитории: мужчины 18-55 лет, женщины 18-45 лет.

Тем не менее большинство опрошенных в рамках проекта для АСИ (65\%), вне зависимости от наличия и числа детей, считают, что меры государственной политики влияют на решение семьи завести ребенка, треть (31\%) уверены, что они на это не влияют (3\% затруднились с ответом). Однако, когда родителям задали вопрос о том, учитывали ли они сами существующие меры государственной поддержки, то утвердительно ответили лишь 13\% опрошенных. При этом даже среди тех, кто считает, что господдержка влияет на репродуктивное поведение, в собственной ситуации учитывали ее лишь 16\% (таблица 11). Разумеется, столь невысокая доля принимавших во внимание поддержку государства не означает, что меры господдержки не находят спроса среди населения. Однако принимая решение, заводить или нет ребенка, люди руководствуются в первую очередь личными мотивами.

Таблица 11. Распределение ответов на вопрос: «Когда Вы принимали решение о рождении ребёнка (для тех, у кого несколько детей - младшего), Вы учитывали или не учитывали существующие меры государственной поддержки?», \% от

\section{опрошенных}

\begin{tabular}{|c|c|c|c|}
\hline & \multirow[t]{2}{*}{ Имеющие детей } & \multicolumn{2}{|c|}{$\begin{array}{c}\text { Меры государственной поддержки рождаемости на решение } \\
\text { семьи завести ребёнка }\end{array}$} \\
\hline & & влияют & не влияют \\
\hline Учитывал(-а) & 13 & 16 & 6 \\
\hline Не учитывал(-а) & 85 & 82 & 91 \\
\hline Затрудняюсь ответить & 3 & 2 & 3 \\
\hline
\end{tabular}




\section{ОТНОШЕНИЕ К ПЛАНИРУЕМЫМ МЕРАМ ДЕМОГРАФИЧЕСКОЙ политики}

Если говорить о еще не принятых, но рассматриваемых на момент опроса мерах, самой востребованной мерой, судя по результатам опроса, является увеличение размеров ежемесячных пособий по уходу за ребенком: о необходимости введения этой меры заявили $61 \%$ опрошенных. На втором месте - продление действия программы материнского (семейного) капитала до конца 2028 г. (38\%). На третьем - снижение ставок по ипотеке для семей с детьми (34\%). Такие меры, как развитие системы государственных финансовых (страховых) гарантий для семьи с детьми, программы содействия занятости отцов (8\%), помощь в оплате услуг для сертифицированных нянь (5\%) особого отклика у населения не нашли. Возможно, в каких-то случаях респондентам не хватило конкретики, как в случае с финансовыми гарантиями (в чем именно будут заключаться эти гарантии?). Другие же из перечисленных мер (например, содействие занятости отцов и помощь в оплате услуг нянь), по нашим предположениям, касаются только определенных, довольно узких групп целевой аудитории. Таким образом, наиболее актуальными и востребованными мерами сегодня попрежнему, с одной стороны, являются финансовые, но с другой - довольно остро стоит «квартирный вопрос».

Востребованность тех или иных мер различается в зависимости от половозрастных характеристик респондента. Женщины по понятным причинам чаще заинтересованы в гибком графике работы, особенно молодые (до 25 лет), среди которых эту меру (обеспечение гибкого графика работы для недавно родивших матерей) отметила как важную каждая третья (32\%). Т. Щурко пишет, что европейские государства, которые поддерживают занятость родителей, демонстрируют более высокие показатели рождаемости (Щурко 2013). А. Шадрина в своей работе «Цена материнства» соглашается с этим выводом и говорит, что «создание условий для совмещения материнства с профессиональной занятостью выступает лучшим мотиватором к рождению детей, чем ликвидация проблемы совмещения семьи и работы путем вывода женщин с рынка труда» (Шадрина 2017: 221).

Женщины более старшего возраста (26-35 лет) чаще остальных выступают за продление программы материнского (семейного) капитала, видимо, имея намерения завести еще одного ребенка (45\%). Женщины в возрастной категории 36+ чаще рассчитывают на увеличение размеров ежемесячных пособий (71\%), а также на расширение перечня возможных направлений для использования материнского (семейного) капитала $(21 \%)$.

Важно, что чем больше детей в семье, тем меньше респонденты заинтересованы в мерах, направленных на занятость и образование, но здесь связь, скорее, обусловлена возрастом, нежели непосредственно числом детей (чем больше детей, тем старше респондент, и наоборот) - для более «возрастных» респондентов вопрос карьеры, как правило, уже решен, а потому менее актуален.

Для москвичей более актуальными являются такие меры, как снижение ставок по ипотеке $(39 \%)$, расширение перечня направлений для использования материнского капитала (22\%), помощь в оплате услуг няни (10\%). Сельчане, в свою очередь, больше 
рассчитывают на финансовые меры: увеличение размера ежемесячных пособий (68\%) и единовременных выплат в связи с рождением ребенка (34\%, таблица 12).

Таблица 12. Распределение ответов на вопрос: «Ниже перечислены меры, которые предлагается ввести в качестве дополнительной поддержки рождаемости в России. Как Вам кажется, какие из них необходимо ввести в первую очередь? (Карточка, не более трёх ответов)», \% от опрошенных

Увеличение размеров ежемесячных пособий по уходу за ребёнком

Продление действия программы материнского (семейного) капитала до 31 декабря 2028 г.

Снижение ставок по ипотеке для семей с детьми, в том числе до нулевой ставки для многодетных семей

Увеличение размеров единовременных выплат в связи с рождением ребёнка

Обеспечение гибкого рабочего графика для матерей, воспитывающих детей

Расширение перечня возможных направлений для использования материнского (семейного) капитала Введение субсидий на аренду жилья для малообеспеченных семей с детьми

Помощь в получении высшего образования для молодых родителей (студентов)

Создание при финансовой поддержке государства жилищных семейных кооперативов для малообеспеченных семей Развитие системы государственных финансовых (страховых) гарантий для семей с детьми

Программы содействия занятости отцов, имеющих детей

Помощь в оплате услуг сертифицированных нянь

Другое

Затрудняюсь ответить

\begin{tabular}{|c|c|c|c|c|c|c|}
\hline \multirow[b]{2}{*}{ 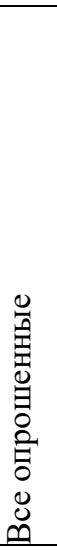 } & \multicolumn{6}{|c|}{ Тип населенного пункта } \\
\hline & 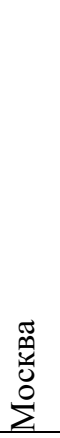 & 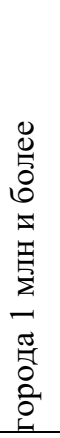 & 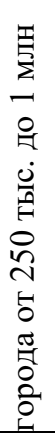 & 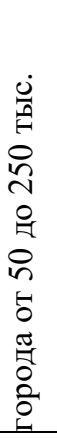 & 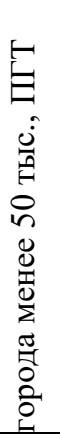 & : \\
\hline 61 & 54 & 49 & 60 & 60 & 67 & 68 \\
\hline 39 & 44 & 36 & 47 & 35 & 39 & 36 \\
\hline 34 & 39 & 37 & 30 & 40 & 33 & 31 \\
\hline 27 & 22 & 22 & 31 & 24 & 25 & 34 \\
\hline 22 & 23 & 24 & 20 & 24 & 25 & 16 \\
\hline 15 & 22 & 15 & 18 & 12 & 15 & 13 \\
\hline 13 & 13 & 18 & 14 & 15 & 12 & 9 \\
\hline 12 & 10 & 14 & 12 & 14 & 13 & 11 \\
\hline 11 & 11 & 10 & 13 & 15 & 11 & 10 \\
\hline 9 & 9 & 12 & 10 & 8 & 8 & 7 \\
\hline 8 & 9 & 9 & 9 & 7 & 11 & 6 \\
\hline 5 & 10 & 7 & 8 & 3 & 5 & 2 \\
\hline 2 & 3 & 3 & 1 & 3 & 1 & 3 \\
\hline 3 & 2 & 3 & 1 & 4 & 3 & 4 \\
\hline
\end{tabular}

Примечание: ПГТ - поселок городского типа.

В целом «рейтинг» предлагаемых государством мер не зависит от репродуктивных намерений респондентов: и те, кто планирует еще детей (таких в нашей выборке 45\%), и те, кто больше детей не хочет (50\%), выбирают примерно один и тот же набор, разве что первые чаще опасаются, что программа материнского (семейного) капитала будет свернута. 


\section{ЗАКЛЮЧЕНИЕ}

Большая часть опрошенных считают, что в последние 2-3 года рождаемость в стране растет. Данные статистики, в свою очередь, показывают, что суммарный коэффициент рождаемости в последние годы снижается и даже по самым оптимистичным прогнозам не достигнет в ближайшие десятилетия уровня простого воспроизводства населения. Репродуктивное поведение населения России все больше походит на модели, характерные для стран Западной Европы: повышается возраст вступления в брак, возраст рождения первого ребенка и др. Однако установки россиян несколько «отстают» от реального поведения. Так, наиболее оптимальным возрастом для рождения первого ребенка большая часть опрошенных считают 21-24 года, у многих респондентов первый ребенок появился именно в этом возрасте.

Наиболее предпочитаемая модель семьи по-прежнему двухдетная. Однако многие из тех, у кого уже есть двое и более детей, в идеальных условиях хотели бы по меньшей мере еще одного ребенка. Но далеко не каждый планирует на практике реализовать это желание - лишь четверть опрошенных в этой группе. Соответственно, можно говорить о существовании определенных барьеров на пути к идеальной семье. Чаще всего, судя по данным опроса для АСИ, люди ссылаются на недостаточную финансовую обеспеченность, отсутствие стабильных источников дохода, отсутствие жилья, т. е. материальные трудности.

Несмотря на это и на тот факт, что самыми востребованными и важными на сегодняшний день мерами по-прежнему оказываются финансовые, рассчитывать на то, что демографическая политика в нынешней преимущественно монетарной форме повлияет на рождаемость, не приходится, что подтверждается как результатами опроса об отношении к материнскому капиталу за первого ребенка, так и «ретроспективными» ответами респондентов с детьми о том, повлияла ли существующая на тот момент государственная поддержка на их решение завести ребенка.

Это не значит, что государство не должно поддерживать родителей, однако его помощь не должна ограничиваться финансовой. Безусловно, сейчас нефинансовые меры поддержки в целом пользуются меньшей популярностью, но возможно, потому, что в нашей стране нет значимого опыта реализации соответствующих программ. Bсе же можно утверждать, что, по меньшей мере, молодые женщины выражают заметную заинтересованность в обеспечении гибкого графика работы для недавно родивших женщин, а молодые мужчины - в помощи в получении образования для молодых родителей.

\section{ЛИТЕРАТУРА}

Белова В.А., Дарский Л.Е. (1972). Статистика мнений в изучении рождаемости. Москва: Статистика. URL: http://www.demoscope.ru/weekly/knigi/belova_darskij/belova_darskij.html

Бодрова В. (2002). Идеальное, желаемое, ожидаемое количество детей: 1991-2000. Демоскоn Weekly, 81-81. URL: http://www.demoscope.ru/weekly/2002/081/tema01.php 
Борисов В.A. (1976). Перспективы рождаемости. Москва: Статистика. URL: http://www.demoscope.ru/weekly/knigi/borisov/borisov.html

Варламова С.Н., Носкова А.В., Седова Н.Н. (2006). Семья и дети в жизненных установках россиян. Социологические исследования, 10, 61-73. URL: http://www.demoscope.ru/weekly/2006/0267/analit02.php

Захаров С.В. (2016). Скромные результаты пронаталистской политики на фоне долговременной эволюции рождаемости в России. Часть 1. Демографическое обозрение, 3(3), 6-38. DOI: https://doi.org/10.17323/demreview.v3i3.1745

Исупова О.Г. (2018). Отношение к мерам стимулирования рождаемости по данным микропереписи 2015 г. Демографическое обозрение, 5(3), 25-56. DOI: https://doi.org/10.17323/demreview.v5i3.8134

Малева Т., Макаренцева А., Третьякова Е. (2017). Пронаталистская демографическая политика глазами населения: десять лет спустя. Экономическая политика, 12(6), 124 147. DOI: $10.18288 / 1994-5124-2017-6-06$

Павлюткин И.В. (2017). Значение религии в современной российской рождаемости. Аист на крыше. Демографический журнал, 4, 34-37. URL: Proaist.ru/journal/vypusk4/znachenie-religii-v-sovremennoy-rossiyskoy-rozhdaemosti-/

Слонимчик Ф., Юрко А.В. (2016). Оценка влияния политики материнского капитала в России. Демографическое обозрение, 2(3), 30-68. DOI: https://doi.org/10.17323/demreview.v2i3.1774

Тындик А. (2012). Репродуктивные установки населения в современной России. SPERO, 16, 95-112. URL: http://www.demoscope.ru/weekly/2013/0553/analit01.php

Фрейка Т., Захаров С.В. (2014). Эволюция рождаемости за последние полвека в России: оптика условных и реальных поколений. Демографическое обозрение, 1(1), 106-143. DOI: https://doi.org/10.17323/demreview.v1i1.1828

Шадрина А. (2017). Дорогие дети. Сокращение рождаемости и рост «цень»» материнства в XXI веке. Москва: Новое литературное обозрение.

Щурко Т. (2013). Детский сад как основа усиления социальных позиций женщин. Наше мнение. URL: https://nmnby.eu/news/analytics/5279.html

Attwood L., Schimpfossl E., Yusupova M. (2018). Gender and Choice After Socialism. Palgrave Macmillan.

Population Policy Acceptance Study - The Viewpoint of Citizens and Policy Actors Regarding the Management of Population Related Change (2006). EU research on social sciences and humanities. Retrieved from: https://cordis.europa.eu/docs/projects/files/HPSE/HPSE-CT-2002-00153/1001243116_en.pdf

Freedman R., Coombs L.C. (1965). Stability and Change in Expectations About Family Size: A Longitudinal Study. Demography, 2, 250-275. DOI: https://doi.org/10.2307/2060117

Westoff C.F., Ryder N.B. (1977). The Predictive Validity of Reproductive Intentions. Demography, 14(4), 431-453. DOI: 10.2307/2060589

Wilson F.D., Bumpass L. (1973). The Prediction of Fertility Among Catholics: A Longitudinal Analysis. Demography, 10(4), 591-597. DOI: https://doi.org/10.2307/2060589 


\title{
REPRODUCTIVE ATTITUDES OF RUSSIANS AND HOW THEY REGARD GOVERNMENT MEASURES TO SUPPORT FERTILITY
}

\section{IRINA OSIPOVA}

This article is written on the basis of a survey conducted for the Agency for Strategic Initiatives by the Public Opinion Foundation and other surveys. The research is devoted, on the one hand, to the reproductive attitudes of men aged 18-55 years and women 18-45 years old. On the other hand, it explores how people relate to measures of demographic policy - both those already existing and those under consideration - and to their effectiveness.

\begin{abstract}
The research shows that the most desired family model in terms of the number of children has not changed over the past ten years. People still want (in ideal conditions) two children. However, people's desires don't fully coincide with their intentions. Only one fourth of respondents say that they plan to have another child. The rest are stopped by material difficulties - a lack of stable sources of income sufficient for the birth and upbringing of another child. For this (but not only this) reason, the most popular demographic measures today are material - the maternity capital, the repayment of mortgage obligations for large families, and a monthly childcare allowance until the child reaches 1.5 years of age.
\end{abstract}

Demographers, however, doubt the effectiveness of such measures in terms of increasing birth rates, and the survey data confirm their doubts. Despite the fact that most respondents believe that demographic policies affect fertility, only a few took them into account when deciding whether or not to have a baby.

Key words: fertility, reproductive intentions, desired family size, family policy, efficiency.

Irina OSIPOva (osipova49@yandex.ru), PUbLic OPINION Foundation (FOM), Russia.

DATE RECEIVED: MARCH 2020.

\section{REFERENCES}

Attwood L., Schimpfossl E., Yusupova M. (2018). Gender and Choice After Socialism. Palgrave Macmillan.

Belova V.A., Darskiy L.E. (1972). Statistika mneniy v izuchenii rozhdaemosti [Statistics of opinions in the study of fertility]. Moscow: Statistika. (In Russ.). Retrieved from http://www.demoscope.ru/weekly/knigi/belova_darskij/belova_darskij.html

Bodrova V. (2002). Ideal'noye, zhelayemoe, ozhidayevoe kolichestvo detey: 1991-2000 [Ideal, desired and expected number of children]. Демоскоп Weekly, 81-81. (In Russ.). Retrieved from http://www.demoscope.ru/weekly/2002/081/tema01.php

Borisov V.A. (1976). Perspektivy rozhdaemosti [Fertility prospects]. Moscow: Statistika. (In Russ.). Retrieved from: http://www.demoscope.ru/weekly/knigi/borisov/borisov.html

Freedman R., Coombs L.C. (1965). Stability and Change in Expectations About Family Size: A Longitudinal Study. Demography, 2, 250-275. DOI: https://doi.org/10.2307/2060117

Frejka T., Zakharov S.V. (2014). Fertility trends in Russia during the past half century: period and cohort perspectives. Demographic Review, 1(1), 106-143. (In Russ.). DOI: https://doi.org/10.17323/demreview.v1i1.1828 
Isupova O.G. (2018). Attitudes to pronatalist policy measures according to the data of the 2015 micro-census. Demographic Review, 5(3), 25-56. (In

Russ.). DOI: https://doi.org/10.17323/demreview.v5i3.8134

Maleva T., Makarentseva A., Tretyakova E. (2017). Pronatalistskaya demographicheskaya politika glazami naseleniya: desyat' let spustya [Pro-natalist demographic policy through the eyes of the population: ten years later]. Economisheskaya politika [Economic Policy], 12(6), 124-147. (In Russ.). DOI: 10.18288/1994-5124-2017-6-06

Pavlutkin I.V. (2017). Znachenie religii v sovremennoy rossiyskoy rozhdaemosti [The importance of religion in modern Russian fertility]. Aist na kryshe. Demographichesliy zhurnal [Stork on the roof. Demographic magazine], 4, 34-37. (In Russ.) Retrieved from: Proaist.ru/journal/vypusk-4/znachenie-religii-v-sovremennoy-rossiyskoy-rozhdaemosti-/

Population Policy Acceptance Study - The Viewpoint of Citizens and Policy Actors Regarding the Management of Population Related Change (2006). EU research on social sciences and humanities. Retrieved from: https://cordis.europa.eu/docs/projects/files/HPSE/HPSE-CT-2002-00153/1001243116_en.pdf

Shadrina A. (2017). Dorogiye deti. Sokrash'eniye rozhdaemosti i rost "tseny" materinctstva $v$ $X X I$ veke [Precious children. The decline in the birth rate and the increase in the "price" of motherhood in the 21st century.]. Moscow: Novoye literaturnoye obozreniye. (In Russ.).

Sh'urko T. (2013). Detskiy sad kak osnova usileniya sotsial'nykh pozitsiy zhenshin. [Kindergarten as a basis for strengthening the social position of women]. Nashe mneniye [Our opinion]. (In Russ.). Retrieved from https://nmnby.eu/news/analytics/5279.html

Slonimczyk F., Yurko A.V. (2016). Assessing the impact of the maternity capital policy in Russia. Demographic Review, 2(3), 30-68. (In Russ.). DOI: https://doi.org/10.17323/demreview.v2i3.1774

Tyndik A. (2012). Reproduktivniye ustanovki naseleniya v sovremennoy Rossii [Fertility attitudes of the population in modern Russia]. SPERO, 16, 95-112. (In Russ.). Retrieved from http://www.demoscope.ru/weekly/2013/0553/analit01.php

Varlamova S.N., A.V. Noskova, N.N. Sedova (2006). Sem'ya i deti v zhiznennykh ustanovkakh rossiyan [Family and children in Russians` life attitudes]. Sotsiologicheskie issledovaniya [Sociological Research]. 10, 61-73. (In Russ). Retrieved from http://www.demoscope.ru/weekly/2006/0267/analit02.php

Westoff C.F., Ryder N.B. (1977). The Predictive Validity of Reproductive Intentions. Demography, 14(4), 431-453. DOI: 10.2307/2060589

Wilson F.D., Bumpass L. (1973). The Prediction of Fertility Among Catholics: A Longitudinal Analysis. Demography, 10(4), 591-597. DOI: https://doi.org/10.2307/2060589

Zakharov S.V. (2016). The modest results of the pronatalist policy against the background of long-term evolution of fertility in Russia. Part 1. Demographic Review, 3(3), 6-38. (In Russ.). DOI: https://doi.org/10.17323/demreview.v3i3.1745 